\title{
Ant and Earthworm Bioturbation in Cold-Temperate Ecosystems
}

\author{
A. R. Taylor, ${ }^{1 *} \odot$ L. Lenoir, ${ }^{1}$ B. Vegerfors, ${ }^{2}$ and T. Persson ${ }^{1}$ \\ ${ }^{1}$ Department of Ecology, Swedish University of Agricultural Sciences, Box 7044, 75007 Uppsala, Sweden; ${ }^{2}$ Department of Energy and \\ Technology, Swedish University of Agricultural Sciences, Box 7032, 75007 Uppsala, Sweden
}

\begin{abstract}
In temperate ecosystems, earthworms and ants are the most important organisms for bioturbation. Little is known about how these groups contribute to bioturbation in different environments and to what extent overall bioturbation depends on their diversity. We developed a formula that allows quantification of annual earthworm bioturbation, thereby taking differences between earthworm ecotypes into account. With this formula, we calculated earthworm bioturbation at three sites, each with vegetation types typically found in Northern Europe. Earthworm bioturbation was low ( $1 \mathrm{Mg}$ dry soil ha $\mathrm{h}^{-1} \mathrm{y}^{-1}$ ) in Scots pine and Norway spruce forests with acidic soil (pH 3.9-4.4) and high (between 15 and $34 \mathrm{Mg}$ dry soil ha ${ }^{-1} \mathrm{y}^{-1}$ ) in broadleaf forests, grasslands, alder carr and spruce forests on calcareous soil. Burrowing (endogeic and anecic) earthworms accounted for most of the earthworm bioturbation, and these worms had the highest population densities at moderate-to-high
\end{abstract}

soil $\mathrm{pH}$ (pH 5-7.2). Estimates of ant bioturbation at the same sites were based on nest abundance, size and residence time. Mean ant bioturbation varied between 0.2 and $1 \mathrm{Mg}$ dry soil ha $\mathrm{h}^{-1} \mathrm{y}^{-1}$, but individual plots had up to $2.4 \mathrm{Mg}$ dry soil ha ${ }^{-1} \mathrm{y}^{-1}$. In soils with $\mathrm{pH}$ higher than 5 , the relative contribution of ants to total bioturbation was only $1-5 \%$. Ant bioturbation was higher than earthworm bioturbation only in some forest soils with $\mathrm{pH}$ 3.9-4.4. Thus, earthworms appear to be the dominant cause of bioturbation in most types of terrestrial ecosystems in the cold-temperate areas of Europe and when information on local earthworm communities and monthly soil temperatures is available, bioturbation can be quantified using the presented 'earthworm bioturbation formula'.

Key words: Aporrectodea caliginosa; egestion; Lumbricidae; Myrmica; nest density; $\mathrm{pH}$; soil turnover; temperature dependence.

Received 20 January 2018; accepted 29 September 2018;

published online 18 December 2018

Author Contribution: T. Persson conceived the funding, designed the study and performed the research together with L. Lenoir and A.R. Taylor. T. Persson developed the model to estimate earthworm bioturbation, L. Lenoir estimated ant bioturbation and A.R. Taylor contributed with new methods for the underlying baseline research. B. Vegerfors analysed the data. A.R. Taylor and T. Persson wrote the paper and L. Lenoir commented on the manuscript.

*Corresponding author; e-mail: astrid.taylor@slu.se

\section{HighLIGHTS}

- We present a method to calculate earthworm and ant bioturbation

- Earthworm and ant bioturbation depended on the species composition

- Earthworm bioturbation was larger than ant bioturbation at soil $\mathrm{pH}>4.3$

\section{INTRODUCTION}

In cold-temperate regions, earthworms and ants are the most important 'ecosystem engineers' (Lavelle and others 1997; Jones and Gutiérrez 2007) 
that significantly affect the structure and function of the ecosystems they inhabit (Folgarait 1998; Le Bayon and others 2017) via their bioturbation activity. Bioturbation, that is, the biological reworking of soils and sediments (Meysman and others 2006), takes place when earthworms and ants transport soil and organic matter from one place to the other. Earthworms translocate and mix soil when feeding/egesting, while ants bioturbate via their nest-building activities.

Earthworm and ant bioturbation contributes to a range of ecosystem services, like decomposition, nutrient cycling, soil structuring/formation and the regulation of water and gas exchange (Lavelle and others 2006; Wall and others 2012). However, the impact of bioturbation on individual services and the temporal and spatial dynamics of their bioturbation activity differ significantly between both groups (Folgarait 1998; Wilkinson and others 2009; Blouin and others 2013; Turbé and others 2010). This is, on the one hand, due to earthworms and ants having different spatial aggregation patterns, dispersal distances and life spans. On the other hand, the longevity and physical and chemical properties of the biotic structures created by both groups above-ground (for example, mounds, nests, casts, middens) and below-ground (for example, galleries, chambers, burrows, casts) are distinctly different (Hedde and others 2005). Earthworm casts and burrows differ from ant artefacts by the origin of their organic matter $(\mathrm{OM})$ and the gut transit experienced before structure building. Thus, the resource quality for microorganisms in these biostructures differs depending on engineer foraging specificity leading to differences in the OM humification rates (Hedde and others 2005). There are only few studies that directly link the functioning of biological soil components like that of soil ecosystem engineers to ecosystem services (Adhikari and Hartemink 2016) because it is inherently difficulty to measure their impact on a particular ecosystem service under field conditions (Barrios 2007).

To assess the full impact of environmental engineering by earthworms and ants in cold-temperate regions, it is important to consider the cumulative effects of bioturbation by both groups and to relate the rate of material transport to their community characteristics, that is, species composition and abundance, in the particular environment investigated (Wilkinson and others 2009). Differences in the bioturbation activity of earthworm species are reflected in the common division into three ecological types (sensu Bouché 1977)—epigeic (surface living), endogeic (shallow burrowing) and anecic (deep burrowing) species-which separates species according to their life history strategies and behaviour. The latter has an impact on the nutritional quality of the food resources consumed which in turn strongly affects species egestion rates and thus bioturbation. Ant bioturbation and its effect on the environment are also largely dependent on the respective ant species and their nestbuilding characteristics (Frouz and Jilková 2008). Although most ants live in below-ground galleries and chambers (Dostál and others 2005), a small group of ants-the majority of which are in the genus Formica-build most of their nest aboveground using needles, twigs, resin and bark collected from the surrounding forest floor (Laakso and Setälä 1998; Jurgensen and others 2008). Nest density, that is, the number of ant nests per area, has been suggested as the most important factor explaining variation in soil turnover by ants between different habitats (Lobry de Bruyn and Conacher 1994).

The goal of the present study was to assess and compare environmental engineering activities of ants and earthworms-using bioturbation as a proxy-in a range of vegetation types shared by both groups. We used an indirect approach to place earthworm and ant bioturbation in a quantitative framework via estimating the amount of soil and OM moved over time by each group. We see this as a first step towards linking empirical data on abundance and composition of soil ecosystem engineer communities with their function in a specific environment and their impact on ecosystem services (Meysman and others 2006). For earthworms, we developed a formula that allows quantifying annual earthworm bioturbation; it is based, amongst other parameters, on the egestion rates of the most common European earthworm species. For ants, calculations of annual bioturbation are based on ant nest density, volume and residence time. For both groups, we distinguish between the contributions of different ant species and earthworm ecotypes.

The present study focusses on the bioturbation of ecosystem engineers in grasslands and cold-temperate forests in Sweden. However, the results will be significant for a much wider region because the vegetation types investigated are typically found all over Scandinavia and even Northern Europe. Particularly in Finland and Sweden, forests account for around $70 \%$ of the land area. In these Scandinavian forests and woodlands, especially those dominated by pine and oak, ants are recognized as important ecosystem engineers (Douwes and others 2012) which may to a certain extent be due to their visual 
presence, for example the large, visible ant mounds often constructed by ants of the genus Formica. Earthworms are assumed to be of lesser importance, particularly in pine- and spruce-dominated forests, because, in contrast to ants, they are negatively affected by low soil pH (Lofs-Holmin 1983; Edwards and Bohlen 1996), which is very common in Scandinavian coniferous forests. Therefore, traditionally far more research focusses on the functional role of earthworms in agricultural fields and grasslands (for example, Scheu 2003) whereas their role in coniferous forests is somewhat neglected. Earthworms and ants are rarely investigated together, and little is known on the proportion between earthworm and ant bioturbation in different environments (Wilkinson and others 2009). The present study is to our knowledge the first to compare both the aboveand below-ground amount of matter moved via bioturbation by two important soil ecosystem engineers in the same habitats. We hypothesized that earthworms dominate annual bioturbation in vegetation types with a soil $\mathrm{pH}$ above 5 , whereas ants are more important bioturbators in more acidic soils. In addition to $\mathrm{pH}$, the amount and quality of organic matter as well as texture were assumed to determine earthworm abundance. Consequently, bioturbation should be earthworm-dominated in most deciduous forests and grasslands (high $\mathrm{pH}$, low $\mathrm{C} / \mathrm{N}$ ratio, fine texture and palatable litter) and ant-dominated in most coniferous forests, characterized by low $\mathrm{pH}$, high $C / N$ ratio, coarse texture and recalcitrant litter.

\section{Materials ANd Methods}

\section{Site Description}

The study was conducted at three sites, all situated in south-eastern Sweden (Table 1). Two of the sites, Forsmark and Oskarshamn, were selected by
SKB, Swedish Nuclear Fuel and Waste Management Company, which needed soil biological data on these two sites for selection of a repository of radioactive waste from nuclear plants. The third site consisted of a number of sub-sites in the Uppsala region, Spikbole, Andersby ängsbackar, Fexboda and Österbybruk (Table 1). The climate at all sites is characterized by semi-arid conditions during the growing season (daily mean $>+5^{\circ} \mathrm{C}$ ) that extends over 180 days (May-September) at Forsmark and Uppsala and over 200 days (April-October) at Oskarshamn (SMHI 2013). The dominant land cover at all three sites is coniferous forest on till soils together with some areas of arable land, deciduous woodland, wetlands and grazed/ungrazed pastures.

At Forsmark and Oskarshamn, two replicate plots $(50 \mathrm{~m} \times 50 \mathrm{~m})$ of five different vegetation types were selected (Table 2 ). The dominant vegetation in the five vegetation types was (1) pine forest with Scots pine Pinus sylvestris L., bilberry Vaccinium myrtillus L., cowberry V. vitis-idaea L. and forest mosses in the tree, field and bottom layers; (2) spruce forest with Norway spruce Picea abies (L.) Karst. and various forest mosses; (3) broadleaf forest with deciduous trees such as common oak Quercus robur L., ash Fraxinus excelsior L., Norway maple Acer platanoides L., hazel Corylus avellana L. and silver birch Betula pendula Roth in the tree layer and various grasses, herbs and mosses as ground vegetation; (4) grasslands with a dominance of grasses and forbs, and (5) alder carr woodland with European alder Alnus glutinosa (L.) Gaertner and downy birch, Betula pubescens Ehrh. in the tree layer and grasses, sedges and mosses as field and bottom layer. The same vegetation types were also studied at Uppsala with the exception of alder carr. The Uppsala site consisted of ten Scots pine forests

Table 1. Geographical Position of the Study Sites and Mean Annual Air Temperature (MAT) and Mean Annual Precipitation (MAP) in 2006

\begin{tabular}{lllllll}
\hline & $\begin{array}{l}\text { Geographical } \\
\text { position }\end{array}$ & $\begin{array}{l}\text { Altitude } \\
(\mathrm{m} \text { a.s.l. })\end{array}$ & $\begin{array}{l}\text { MAT } \\
\left({ }^{\circ} \mathrm{C}\right)\end{array}$ & $\begin{array}{l}\text { MAP } \\
(\mathrm{mm})\end{array}$ & $\begin{array}{l}\text { Vegetation } \\
\text { types }\end{array}$ & $\begin{array}{l}\text { Sampling } \\
\text { year }\end{array}$ \\
\hline $\begin{array}{l}\text { Forsmark } \\
\text { Uppsala }\end{array}$ & $60^{\circ} 22^{\prime} \mathrm{N}, 18^{\circ} 13^{\prime} \mathrm{E}$ & $1-20$ & 7.0 & 600 & See Table 2 & 2006 \\
$\quad$ & & & & & \\
$\quad$ Österbybruk & $60^{\circ} 12^{\prime} \mathrm{N}, 17^{\circ} 54^{\prime} \mathrm{E}$ & $20-40$ & 7.0 & 600 & Scots pine & 2009 \\
$\quad \begin{array}{l}\text { Fexboda } \\
\text { Andersby ängsbackar }\end{array}$ & $60^{\circ} 00^{\prime} \mathrm{N}, 17^{\circ} 35^{\prime} \mathrm{E}$ & 25 & 7.0 & 600 & Norway spruce & 1987 \\
$\quad 60^{\circ} 09^{\prime} \mathrm{N}, 17^{\circ} 49^{\prime} \mathrm{E}$ & $25-35$ & 7.0 & 600 & Broadleaf & $1971-1972$ \\
$\quad \begin{array}{l}\text { Spikbole } \\
\text { Oskarshamn }\end{array}$ & $60^{\circ} 00^{\prime} \mathrm{N}, 17^{\circ} 19^{\prime} \mathrm{E}$ & $42-44$ & 7.0 & 600 & Grassland & $1971-1972$ \\
& $57^{\circ} 25^{\prime} \mathrm{N}, 16^{\circ} 33^{\prime} \mathrm{E}$ & $1-20$ & 7.5 & 570 & See Table 2 & 2006
\end{tabular}

The Uppsala site consists of four different sub-sites, which were sampled in different years. 


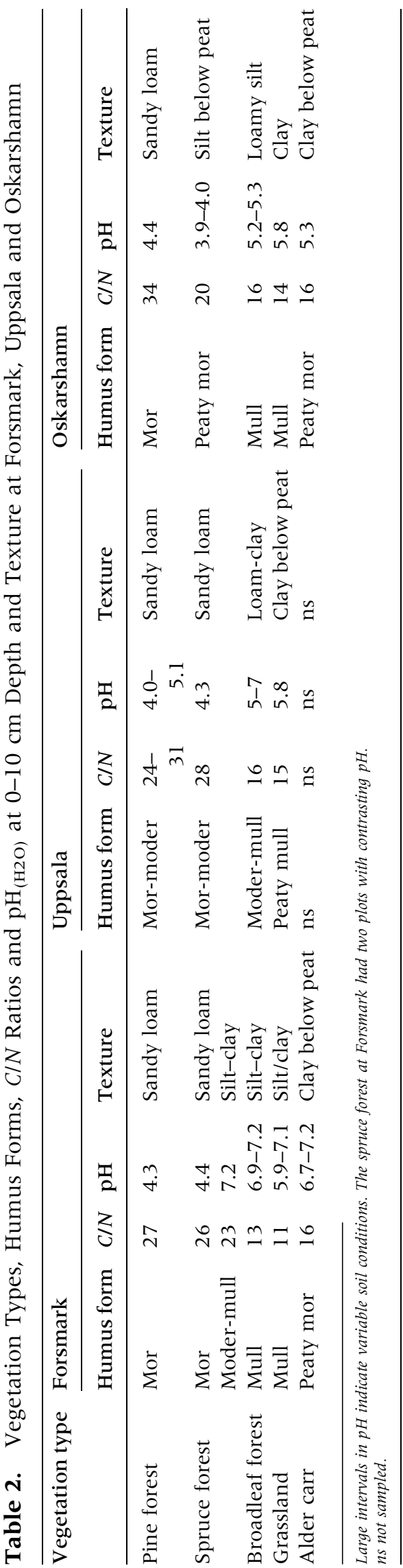

near Österbybruk with variable ground vegetation (grasses, dwarf shrubs, mosses); a Norway spruce forest with forest mosses at Fexboda; a broadleaf forest with grasses, herbs and mosses at Andersby ängsbackar; and an abandoned grassland with a dominance of couch grass Elymus repens (L.) Gould at Spikbole. For a detailed site description, see Persson and Lohm (1977) for Spikbole, Axelsson and others (1984) for Andersby ängsbackar, Staaf and others (1996) for Fexboda, Lundin and others (2004, 2005) for Forsmark and Oskarshamn and Persson and others (2017) for Österbybruk.

\section{Earthworm Sampling}

Field sampling of earthworms at Forsmark and Oskarshamn was mainly performed in early May 2006 (Table 1). To estimate the earthworm populations at Forsmark and Oskarshamn, four replicate soil samples from each of the two plots per vegetation type were taken with a $20 \times 20 \mathrm{~cm}^{2}$ metal frame to a depth of $40 \mathrm{~cm}$. All soil from a depth of $20-40 \mathrm{~cm}$ was hand-sorted in the field, whereas the topsoil $(0-20 \mathrm{~cm})$ was transferred to the laboratory, where it was hand-sorted for earthworms followed by extraction in Tullgren funnels (4 days) to capture smaller, juvenile earthworms. Earthworms were counted, determined to species, dried for $24 \mathrm{~h}$ at $105^{\circ} \mathrm{C}$ and weighed individually (gut content included) to determine individual body dry weight $(\mathrm{dw})$ and biomass.

At Spikbole and Andersby ängsbackar, samples $\left(25 \times 25 \mathrm{~cm}^{2}, 30 \mathrm{~cm}\right.$ depth) were taken in May, June, September, October and November 1971; on each occasion, 15 samples were taken at Spikbole and 10 at Andersby ängsbackar. At Fexboda and Österbybruk, sampling took place in October 1987 and November 2009. The site at Fexboda had 4 replicate plots, and on each sampling occasion, five $125 \mathrm{~cm}^{2}$ samples were taken per plot. The site at Österbybruk consisted of 10 replicate plots, and twenty $100 \mathrm{~cm}^{2}$ samples per plot were taken on each sampling occasion. Fauna extraction from all samples-from the Uppsala sub-sites and from Forsmark and Oskarshamn-followed the same methodology.

Species determination was done using keys by Sims and Gerard (1985), Andersen (1997) and Hale (2007). The developmental stage of each earthworm was noted. Animals with fully developed clitellum were considered as adults; otherwise, they were classified as juveniles. All species were assigned to one of the three earthworm ecotypes (epigeics, endogeics and anecics) based on Bouché (1977). Abundance and biomass were expressed as ind. $\mathrm{m}^{-2}$ and $\mathrm{g} \mathrm{dw} \mathrm{m}^{-2}$, respectively. 


\section{Ant Sampling}

Ants were studied at Forsmark and Oskarshamn in all vegetation types, but at Uppsala the studies were restricted to a spruce forest with unusually high number of large Formica nests to obtain, as we thought, a maximum value of ant bioturbation. Ant nest density was estimated by counting all conspicuous ant mounds at each plot and calculating the number of nests per ha. In addition, the density of less conspicuous mounds in the soil or under stones was estimated by counting all mounds along 2-3 transects ( $3 \mathrm{~m}$ width) across each plot. Total transect length varied between 95 and $150 \mathrm{~m}$ at Forsmark and 50 and $90 \mathrm{~m}$ at Oskarshamn depending on the plot size. Every stone and piece of dead wood was turned over along each transect. Tussocks were opened up with a knife, and all other possible sites for ant nests were investigated. In addition, ant community composition at the plots was investigated with pitfall traps. The traps $(30 \mathrm{ml}$ plastic cups, $3 \mathrm{~cm}$ diam.) were filled to one-third with a mixture of tap water and detergent. Nine traps were placed randomly at each plot at Forsmark and Oskarshamn, keeping the distance between individual traps at a minimum of $7 \mathrm{~m}$. They remained in the field for $96 \mathrm{~h}$ during the periods of 15-19 May at Oskarshamn and 23-28 August at Forsmark. Due to that ant activity (and therefore the likelihood to capture them in pitfall traps) is strongly affected by weather conditions (Hölldobler and Wilson 1990), this approach was chosen to sample periods with similar weather conditions (hours of sunshine) and air temperature for both sites. Ants were determined to species level in the laboratory using the key by Seifert (1996).

At each plot, diameter and height of all clearly visible mounds of Lasius and Formica were measured, and one-fourth of each mound was sampled to determine the mound volume in the field. The nest boundaries were defined as the outer presence of galleries and chambers. Sub-samples of the above- and below-ground nest material were taken to the laboratory for determination of dry weight. Below-ground nests of Myrmica spp. were sampled as a whole. Each nest was wrapped up tightly in a plastic bag, and the total nest volume was determined by submerging the bag in a water-filled graduated cylinder. All nests and nest material were dried at $105{ }^{\circ} \mathrm{C}$ for $24 \mathrm{~h}$ to determine dry weight.

\section{Earthworm Bioturbation}

Annual bioturbation of earthworm field populations calculated for the three earthworm ecotypes (epigeics, endogeics and anecics) was based on the following parameters (1) abundance and biomass of all earthworm species in the field (see above), (2) daily egestion rates for the three ecotypes at $15{ }^{\circ} \mathrm{C}$ (laboratory conditions, see below), (3) an estimate of temperature dependence of earthworm activity (that is, egestion) to calculate a conversion factor for the conversion of egestion rates from laboratory to field conditions (see below) and (4) mean monthly soil temperature in the field.

\section{Daily Egestion Rates}

Two laboratory experiments on earthworm gut transit time and gut content were performed for Aporrectodea caliginosa and Lumbricus terrestris to estimate how much soil material passes through the gut of an earthworm per hour (at $15^{\circ} \mathrm{C}$ ). The results of the experiments were used to calculate an average daily egestion rate $\left(\mathrm{g} \mathrm{dw}\right.$ faeces $\mathrm{g}^{-1}$ body $\mathrm{dw}$ day $^{-1}$ ) for the two earthworm species. In the present study, we used the egestion rate of A. caliginosa for all endogeic species, which are soil feeders (geophagous), and that of L. terrestris for all anecic and epigeic species, both of which are litter feeders (detritivores), assuming that the species within each ecotype had similar metabolic rates (Byzova 1965). A detailed description of both experiments is given in Taylor and Taylor (2014).

\section{Temperature Dependence of Earthworm Egestion}

In order to extrapolate daily egestion rates at $15{ }^{\circ} \mathrm{C}$ to bioturbation rates over a whole year, it was necessary to account for the strong effect of temperature on earthworm activity which consequently also affects faeces egestion. Therefore, we studied the growth rate of field-sampled A. caliginosa at different temperatures in the laboratory and used the temperature dependence obtained from this growth study as a proxy for the temperature dependence of earthworm egestion, being aware of the fact that some ingestion and egestion can occur without any increase in body weight.

Growth rates were recorded over a period of 166 weeks. Newly hatched earthworms were placed in 80 separate plastic bags filled with $2 \mathrm{~L}$ mull topsoil taken from 0 to $5 \mathrm{~cm}$ depth in an oak/hazel/birch forest described in Axelsson and others (1984). A leaf litter layer from the same forest was placed on the top of the soil. The bags were placed in constant-temperature rooms of 4, 5.8, 10 and $20.5^{\circ} \mathrm{C} ; 20$ bags in each room. Soil moisture was kept constant by regular addition of water, and the soil was replaced every second month to avoid food limitation. Every 14 days, the worms were rinsed in tap water and quickly dried 
on filter paper, and their fresh weight (fw) was recorded, after which they were returned to the bag with the soil for another incubation period. The worms were followed during their whole life time, and the time between hatching and appearance of a clitellum was noted because a clitellum appears at different weights depending on the temperature (Lofs-Holmin 1983). Mean growth rate (mg fw day $^{-1}$ ) during the period to reach maturity was calculated for each worm. The mean weight ( \pm SE) for appearance of a clitellum at $20.5^{\circ} \mathrm{C}$ was $362 \pm 21 \mathrm{mg}$ (Table 3 ). We used this as the target weight to determine development times at other temperatures. The temperature dependence based on growth rates followed a quadratic equation of the form $y=a x^{2}+b x$ (see "Results" section).

\section{Earthworm Field Bioturbation}

Earthworm bioturbation was estimated as total faeces production $\mathrm{m}^{-2}$ during a whole year in the field. Thus, daily egestion rates estimated at $15{ }^{\circ} \mathrm{C}$ in the laboratory (see above) had to be adjusted to the appropriate soil temperatures in the field. We used the same temperature dependence for egestion rates as for earthworm growth rate $(A$. caliginosa). Because data on soil temperatures were lacking for Forsmark and Oskarshamn, we based the estimates on monthly mean soil temperatures measured at $10 \mathrm{~cm}$ depth at the meteorological station Ultuna, Uppsala. Uppsala has slightly higher air temperature than Forsmark and slightly lower air temperature than Oskarshamn (Table 4). Earthworm activity is also dependent on soil moisture; however, the present bioturbation calculations do not account for dry periods where earthworm activity may be suppressed by drought (but see discussion).

\section{Ant Bioturbation}

Bioturbation by ants per hectare and year was calculated as no. of ant nests $\mathrm{ha}^{-1} \times$ nest dry weight divided by nest residence time. Literature data on residence times are rare. The residence time used in this study was 20 years for conspicuous nests of $L$. niger and Formica spp., 5 years for small and below-ground nests of L. niger and 0.4 years for nests of Myrmica spp. (Jakubczyk and others 1972).

\section{Data Treatment}

Mean ( \pm SE) earthworm abundance, biomass and bioturbation were estimated for each of the 5 vegetation types with sites as replicates $(n=3$ in most cases, alder forests were studied at only two sites). Mean ( \pm SE) abundance of ant nests, ant bioturbation and total ant + earthworm bioturbation were estimated for two sites. Earthworm bioturbation was compared in the five vegetation types by means of ANOVA with site as replicate (block) and vegetation type (treatment) as fixed factor using the general linear model (GLM) procedure in SAS for Windows (version 9.1). The data were log-transformed before calculation. TukeyKramer test was used to examine pair-wise differences between treatments. The two spruce forest plots at Forsmark had very different topsoil $\mathrm{pH}$, one with $\mathrm{pH} 4.4$ and one with $\mathrm{pH} 7.2$, which also affected the earthworm community. Therefore, this spruce forest was stratified into one stratum with low $\mathrm{pH}$ and one with high $\mathrm{pH}$. Only the spruce data from the low-pH stratum at Forsmark were used in the ANOVA. The spruce data from the high-pH stratum at Forsmark were treated separately, using the samples as replicates when calculating SE. Ant bioturbation was similarly compared in the 5 vegetation types by means of ANOVA.

\section{Results \\ Earthworms \\ Community Characteristic in the Vegetation Types}

Nine, eight and six species of earthworms were found at Forsmark, Oskarshamn and Uppsala, respectively (Table 5). Viewed over all sites, pine and spruce forests with acidic soils had significantly lower abundances of burrowing (endogeic and

Table 3. Time Needed for Juvenile Aporrectodea caliginosa to Reach a Fresh Weight (fw) of $362 \mathrm{mg}$ (Mean fw at First Appearance of Clitellum at $20.5{ }^{\circ} \mathrm{C}, n=18$ ) and Mean Daily Growth Rate at Different Constant Air Temperatures in the Laboratory

\begin{tabular}{lclc}
\hline Temp. $\left({ }^{\circ} \mathrm{C}\right)$ & Time $($ days $)( \pm \mathrm{SE})$ & Daily growth rate $\left(\mathrm{mg} \mathrm{g}^{-1} \mathrm{fw} \mathrm{d}^{-1}\right)$ & No. of worms \\
\hline 20.5 & $140 \pm 7$ & 7.14 & 18 \\
10.0 & $412 \pm 30$ & 2.43 & 12 \\
5.8 & $776 \pm 33$ & 1.29 & 8 \\
4.0 & $1162 \pm 82$ & 0.86 & 5 \\
\hline
\end{tabular}


Table 4. Monthly Air and Soil Temperatures in 2006 at Meteorological Stations from the Swedish Meteorological and Hydrological Institute Close to the Investigated Field Sites Forsmark (Film Meteorological Station), Oskarshamn (Målilla Meteorological Station) and Uppsala (Ultuna Meteorological Station)

\begin{tabular}{|c|c|c|c|c|c|c|}
\hline Month & $\begin{array}{l}\text { Air temp. } \\
\left({ }^{\circ} \mathrm{C}\right) \text { film }\end{array}$ & $\begin{array}{l}\text { Air temp. } \\
\left({ }^{\circ} \mathrm{C}\right) \text { Målilla }\end{array}$ & $\begin{array}{l}\text { Air temp. } \\
\left({ }^{\circ} \mathrm{C}\right) \text { Uppsala }\end{array}$ & $\begin{array}{l}\text { Soil temp. }\left({ }^{\circ} \mathrm{C}, 10 \mathrm{~cm}\right. \\
\text { depth) Uppsala }\end{array}$ & $\begin{array}{l}\text { Daily growth rate } \\
\left(\mathrm{mg} \mathrm{g}^{-1} \mathrm{fw} \mathrm{d} \mathrm{d}^{-1}\right)\end{array}$ & $\begin{array}{l}\text { Monthly growth } \\
\left(\mathrm{mg} \mathrm{g}^{-1} \mathrm{fw}\right)\end{array}$ \\
\hline January & -4.2 & -5.0 & -3.6 & 1.28 & 0.22 & 6.84 \\
\hline February & -3.7 & -3.4 & -3.5 & 0.53 & 0.09 & 2.44 \\
\hline March & -5.5 & -4.0 & -4.7 & 0.39 & 0.06 & 1.98 \\
\hline April & 4.4 & 5.3 & 5.0 & 2.71 & 0.50 & 15.04 \\
\hline May & 9.9 & 10.9 & 10.7 & 8.95 & 2.17 & 67.31 \\
\hline June & 15.9 & 16.6 & 16.4 & 14.42 & 4.22 & 126.65 \\
\hline July & 18.9 & 20.1 & 16.7 & 14.63 & 4.31 & 133.70 \\
\hline August & 17.7 & 16.6 & 17.9 & 17.49 & 5.61 & 174.00 \\
\hline September & 13.6 & 14.5 & 14.3 & 14.34 & 4.19 & 125.59 \\
\hline October & 7.8 & 9.4 & 8.8 & 10.61 & 2.74 & 84.80 \\
\hline November & 3.2 & 4.5 & 4.0 & 4.27 & 0.85 & 25.54 \\
\hline December & 3.2 & 4.1 & 4.0 & 3.29 & 0.63 & 19.42 \\
\hline \multicolumn{6}{|c|}{ Annual growth rate (field conditions: field soil temperature) } & 783 \\
\hline \multicolumn{6}{|c|}{ Annual growth rate (lab. conditions: $15^{\circ} \mathrm{C}$ ) $=4.47$ (daily growth rate at $15^{\circ} \mathrm{C}$ ) $\times 365$} & 1632 \\
\hline \multicolumn{6}{|c|}{ Lab./field conversion factor for egestion rates } & 0.48 \\
\hline
\end{tabular}

Daily growth rates and monthly growth of Aporrectodea caliginosa under field conditions were based on the equation $y=0.0092 x^{2}+0.1601 x(x=$ soil temperature at $10 \mathrm{~cm}$ depth, ${ }^{\circ} \mathrm{C}$ ). In the bottom rows, the calculation of a conversion factor for the relation between earthworm growth in the field and in the laboratory (constant reference temperature of $15^{\circ} \mathrm{C}$ as used in the laboratory gut transit experiment) is shown.

anecic) earthworms $(P<0.05)$ than the other vegetation types, but the abundance of epigeic earthworms and total earthworms did not differ between sites (Figure 1A). Characteristically, earthworm communities in the acidic pine and spruce forests were dominated by epigeic earthworms, particularly the small-sized Dendrobaena octaedra. Burrowing earthworms, on the other hand, occurred in high numbers and dominated the communities in the broadleaf, grassland and alder vegetation types at all sites and in the high-pH spruce forest plot at Forsmark.

Mean earthworm biomass varied between 1 and $19 \mathrm{~g}$ dry weight $\mathrm{m}^{-2}$, with low biomass in the pine and low-pH spruce ecosystems and high biomass, especially in the high-pH spruce and broadleaf forests (Figure 1B). High earthworm biomass was generally associated with high abundance of endogeic and anecic earthworms, while the smallbodied epigeic earthworms only made a minor contribution to total biomass even when occurring in higher numbers (Figure 1A \& B).

\section{Earthworm Bioturbation}

Laboratory incubation of $A$. caliginosa at different temperatures revealed a strong link between temperature and the time span needed to reach a body fresh weight ( $\mathrm{fw}$ ) of $362 \mathrm{mg}$ (Table 3). The relation between temperature and growth rate was curvilinear and followed the equation $y=0.0092 x^{2}+$ $0.1601 x$, where $y$ is the body weight ( $\mathrm{g} \mathrm{fw}$ ) and $x$ is the soil temperature $\left({ }^{\circ} \mathrm{C}\right.$; Figure 2$)$. With this equation, the growth rate under field conditions can be calculated for $A$. caliginosa, when the soil temperature is known.

Monthly and annual growth rates for $A$. caliginosa during the year 2006 (when a major part of the present study was conducted) were simulated using soil temperature measurements at $10 \mathrm{~cm}$ depth from Ultuna meteorological station, Uppsala (Table 4). Table 4 also clearly shows the strong discrepancy between monthly air and soil temperatures. Therefore, information on soil temperature is indispensable for calculating worm bioturbation.

Earthworm bioturbation was calculated for each of the three ecotypes under the assumption that egestion rate and body growth rate had similar temperature dependence. According to the equation $\mathrm{y}=0.0092 x^{2}+0.1601 x$ (see above), mean annual growth of juvenile A. caliginosa was estimated as $783 \mathrm{mg}$ fw for the monthly mean soil temperatures (varying between 0.4 and $17.5^{\circ} \mathrm{C}$ ) found in the field for 2006 (Table 3). The corresponding estimate for a stable temperature of $15{ }^{\circ} \mathrm{C}$ throughout the year would be $1632 \mathrm{mg}$ fw. Thus, the annual growth at field soil temperatures in 
Table 5. Earthworm and Ant Species Found (+) at the Different Sites

\begin{tabular}{|c|c|c|c|c|}
\hline & Ecotypes & Forsmark & Uppsala & Oskarshamn \\
\hline \multicolumn{5}{|l|}{ Earthworms } \\
\hline Eiseniella tetraedra (Sav.) & Epigeic & + & & \\
\hline Dendrobaena octaedra (Sav.) & Epigeic & + & + & + \\
\hline Dendrodrilus rubidus (Sav.) & Epigeic & + & + & + \\
\hline Lumbricus rubellus Hoffm. & Epigeic & + & + & + \\
\hline L. terrestris $\mathrm{L}$. & Anecic & + & + & + \\
\hline Aporrectodea caliginosa (Sav.) & Endogeic & + & + & + \\
\hline A. rosea (Sav.) & Endogeic & + & + & + \\
\hline Octolasion cyaneum (Sav.) & Endogeic & + & & + \\
\hline Octolasion lacteum Örley & Endogeic & + & & + \\
\hline \multicolumn{5}{|l|}{ Ants } \\
\hline Camponotus herculeanus L. & & + & & \\
\hline Formica exsecta Nyl. & & + & & \\
\hline Formica fusca L. & & + & & + \\
\hline F. polyctena Förster & & + & & + \\
\hline F. pratensis Retzius & & + & & \\
\hline F. sanguinea Latreille & & & & + \\
\hline Lasius brunneus (Latreille) & & + & & + \\
\hline L. flavus (Fabr.) & & + & & + \\
\hline L. niger L. & & + & & + \\
\hline Leptothorax gredleri Mayr & & + & & + \\
\hline Myrmica lobicornis Nyl. & & + & & + \\
\hline M. rubra (L.) & & + & & + \\
\hline M. ruginodis Nyl. & & + & & + \\
\hline M. scabrinodis Nyl. & & + & & + \\
\hline M. schencki Viereck & & & & + \\
\hline
\end{tabular}

2006 would be $48 \%$ of that at $15{ }^{\circ} \mathrm{C}$. Due to that the egestion rates for the anecic L. terrestris and endogeic A. caliginosa- 0.66 and $1.16 \mathrm{~g} \mathrm{dw}$ soil $\mathrm{g}^{-1}$ body dw day ${ }^{-1}$, respectively (Taylor and Taylor 2014) —only apply for a temperature of $15^{\circ} \mathrm{C}$ (see above), we used the correction factor of 0.48 to adjust the annual egestion at the laboratory temperature of $15{ }^{\circ} \mathrm{C}$ to that in the field. Thus, annual bioturbation per ecotype at Forsmark, Uppsala and Oskarshamn was calculated as:

Bioturb $_{\text {ane+epi }}\left(\mathrm{g} \mathrm{dw} \mathrm{m}^{-2} \mathrm{y}^{-1}\right)=\operatorname{Biomass}\left(\mathrm{g} \mathrm{dw} \mathrm{m}^{-2}\right)$ $* 0.66 * 0.48 * 365$ (anecic/epigeic earthworms)

Bioturb $_{\text {endo }}\left(\mathrm{g} \mathrm{dw} \mathrm{m}^{-2} \mathrm{y}^{-1}\right)=$ Biomass $\left(\mathrm{g} \mathrm{dw} \mathrm{m}^{-2}\right)$

$* 1.16 * 0.48 * 365$ (endogeic earthworms)

The estimated earthworm bioturbation ranged from 1 to $34 \mathrm{Mg} \mathrm{dw}$ soil ha ${ }^{-1} \mathrm{y}^{-1}$ in the five vegetation types (Figure 3). According to the ANOVA, in which the high-pH plot at Forsmark was not included, the earthworm bioturbation was significantly lower $(P<0.01)$ in the (low$\mathrm{pH})$ spruce forest soils than in the broadleaf forest, grassland and alder carr soils, and the bioturbation in the pine forest soils was lower than in the broadleaf forest soils $(P<0.05)$. Burrowing endogeic and anecic earthworms accounted for $95-98 \%$ of the total worm bioturbation. In the low-pH pine and spruce ecosystems, where these earthworms occurred only sporadically, earthworm bioturbation was very low and largely due to epigeic species.

\section{Ants}

A total of 15 different ant species were found when using pitfall trapping and transect surveys at Forsmark and Oskarshamn (Table 5). Below-ground nests of Myrmica spp. occurred at all sites. The number of clearly visible ant nests above-ground was very low at most vegetation types, and large ant mounds were restricted to one of the two grassland plots at Forsmark, where five mounds of Formica exsecta and three mounds of Lasius niger were observed. Small below-ground nests of L. niger (mean dry weight $1.5 \mathrm{~kg}$ ) were found in the pine, broadleaf and grassland ecosystems at 

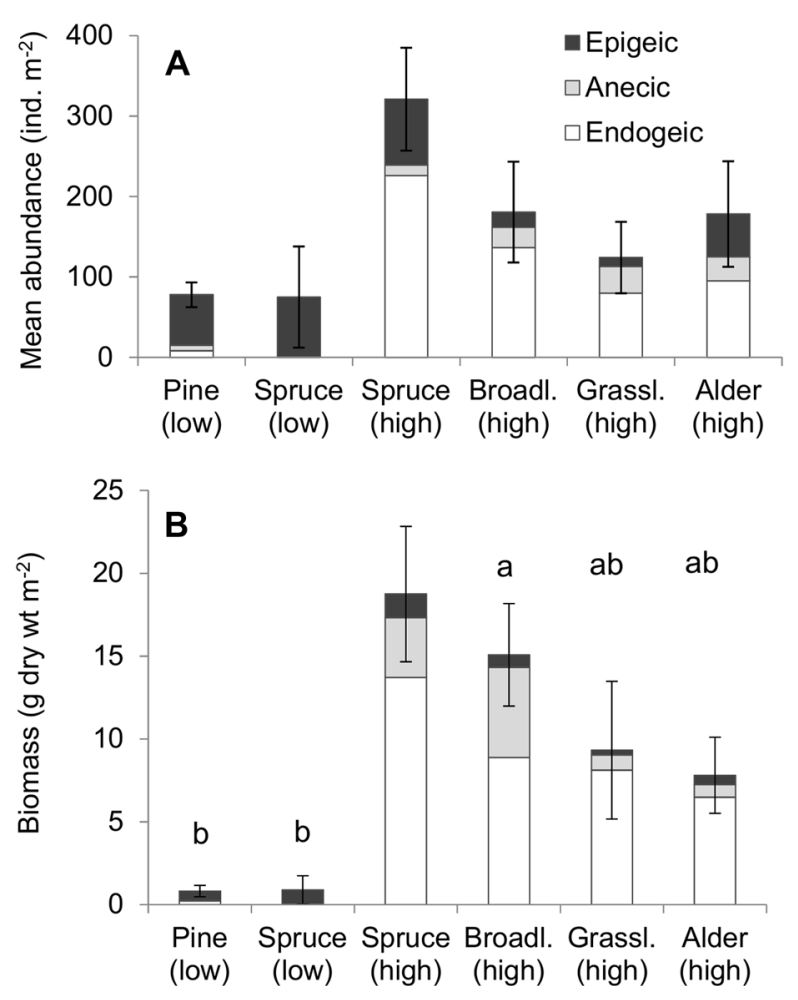

Figure 1. Mean abundance (A) and biomass (B) of earthworms (see legend for the contribution of individual ecotypes) in different vegetation types (pine forests, spruce forests, broadleaf forests, grasslands and alder carr) at three sites (Forsmark, Uppsala and Oskarshamn). Soil pH is indicated as (low) when 3.95.1 or (high) when 5-7.2. Error bars indicate SE for total abundance and biomass. Significant differences $(P<0.05)$ between vegetation types are indicated by different letters. The bar 'Spruce (high)' shows the results obtained at a deviating plot at Forsmark with calcareous soil (not included in the ANOVA).

Oskarshamn. Below-ground nests of Myrmica spp. occurred at all sites.

Mean dry weight of Myrmica nests was $0.96 \mathrm{~kg}$, whereas the mean weight of L. niger nests was estimated to be $1.5 \mathrm{~kg}$ at Oskarshamn and $390 \mathrm{~kg}$ in a dry grassland at Forsmark, that is, more than 200 times heavier than at Oskarshamn. F. exsecta had nests of $49 \mathrm{~kg}$ at the same site. The grassland plot with large nests of Lasius and Formica had higher ant bioturbation, $2.4 \mathrm{Mg} \mathrm{dw}$ soil/litter ha ${ }^{-1}$ $\mathrm{y}^{-1}$, than any other plots studied. Mean ant bioturbation (no. of nests ha ${ }^{-1} \times$ nest dw/nest residence time) estimated for the different vegetation types was found to vary between 0.2 and $1.0 \mathrm{Mg}$ dw soil/litter ha ${ }^{-1} y^{-1}$ (Figure 4), but no significant differences between vegetation types were detected.

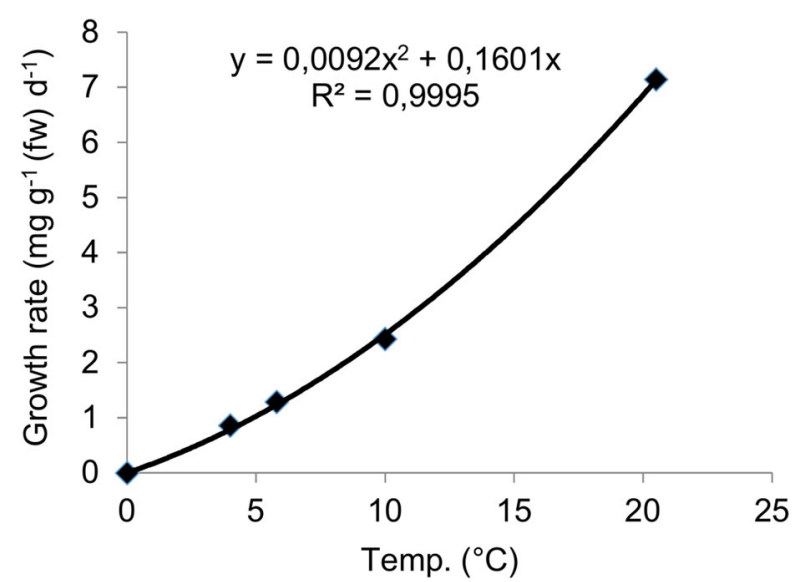

Figure 2. Relationship between temperature and mean growth rate $\left(\mathrm{mg} \mathrm{g}^{-1}\right.$ fresh weight $\left.\mathrm{d}^{-1}\right)$ of juvenile Aporrectodea caliginosa based on laboratory incubations of A. caliginosa at four constant temperatures (represented by black diamonds: 4.0, 5.8, 10.0 and $20.5^{\circ} \mathrm{C}$ ). The equation assumes that there is no growth at $0{ }^{\circ} \mathrm{C}$.

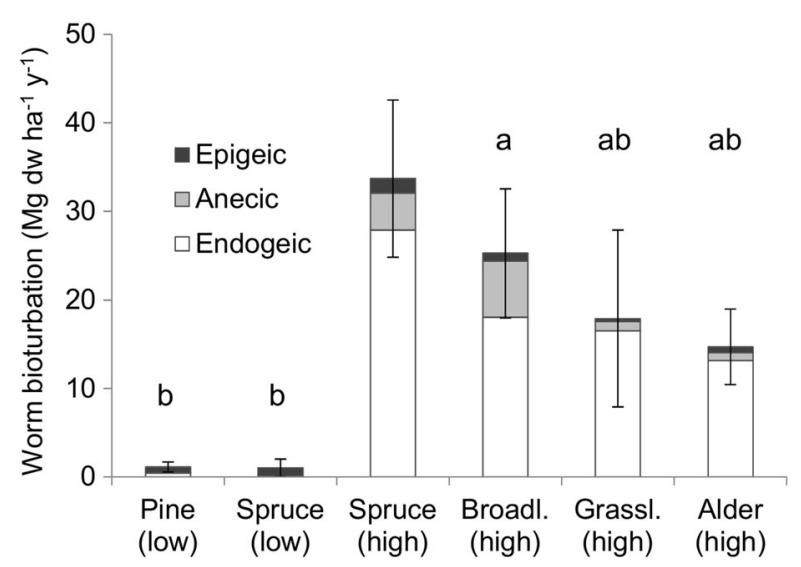

Figure 3. Mean annual earthworm bioturbation in different vegetation types at three sites (Forsmark, Uppsala and Oskarshamn). Significant differences $(P<0.05)$ for total worm bioturbation between vegetation types are indicated by different letters. For other explanations, see Figure 1.

We did not find any large Formica mounds in the forest plots in Forsmark and Oskarshamn which is unusual for these kinds of forests in Sweden. To nevertheless determine the impact of Formica ants on bioturbation, we studied a spruce forest near Uppsala that had a high average nest density of 11 nests per hectare. With a mean dry weight of $955 \mathrm{~kg}$ per nest $(n=5)$, this amounts to a mean nest dry weight of $10.5 \mathrm{Mg} \mathrm{ha}^{-1}$. Estimating a residence time of 20 years, a yearly soil/litter turnover of about $0.5 \mathrm{Mg} \mathrm{ha}^{-1} \mathrm{y}^{-1}$ can be calculated. When combining the results for Myrmica and 


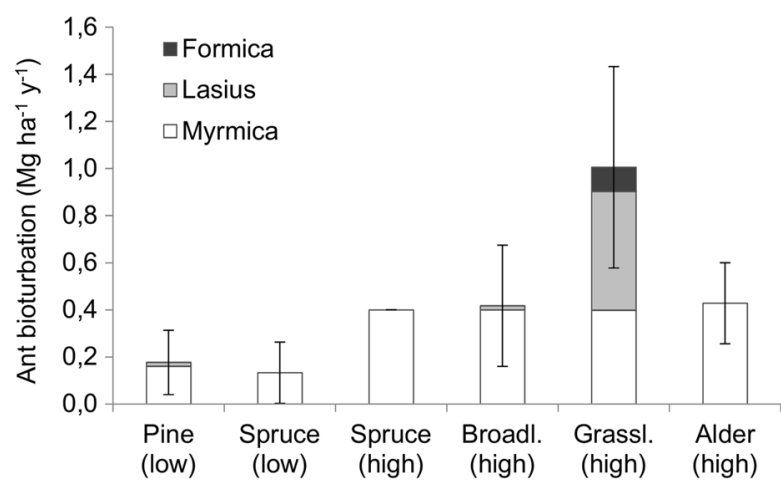

Figure 4. Mean annual bioturbation by ants estimated from abundance, size and turnover of ant nests of Myrmica spp., Lasius niger and Formica exsecta in different vegetation types (pine forests, spruce forests, broadleaf forests, grasslands and alder carr) at two sites (Forsmark and Oskarshamn). Error bars indicate SE for total ant bioturbation.

Lasius bioturbation from the spruce forests in Forsmark and Oskarshamn $\left(0.2 \mathrm{Mg} \mathrm{ha}^{-1} \mathrm{y}^{-1}\right)$ with the Formica bioturbation results from the spruce forest at Uppsala-where the other two species were not studied-total ant bioturbation was $0.7 \mathrm{Mg} \mathrm{ha}^{-1} \mathrm{y}^{-1}$. We think that this result is more representative for the general ant bioturbation in these kinds of Swedish forests.

\section{Earthworm and Ant Bioturbation}

Mean total bioturbation in the individual vegetation types ranged from 0.2 (low-pH spruce forests) to 34 (high-pH spruce forest) $\mathrm{Mg} \mathrm{dw} \mathrm{ha}{ }^{-1} \mathrm{y}^{-1}$ at the two sites where both ants and earthworms

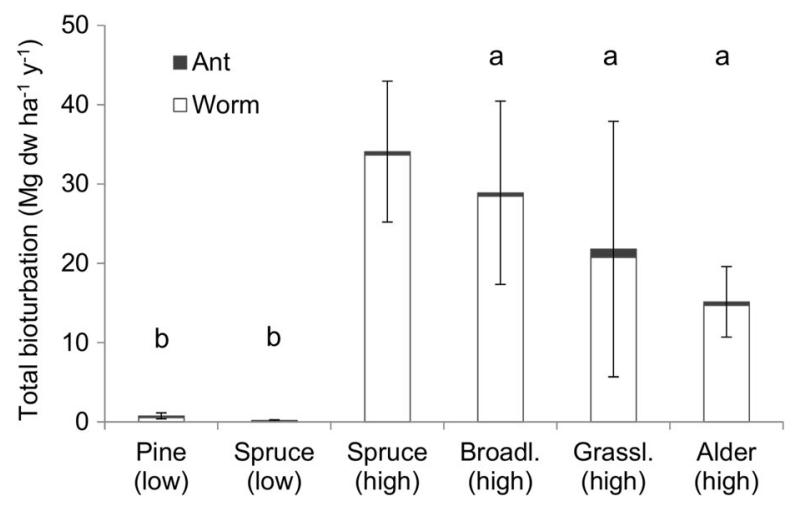

Figure 5. Mean annual bioturbation of ants and earthworms in different vegetation types at the two sites Forsmark and Oskarshamn. Significant differences $(P<0.05)$ for total worm and ant bioturbation between vegetation types are indicated by different letters. For other explanations, see Figure 1. were studied (Figure 5). Earthworm bioturbation was on average 38 times greater than ant bioturbation. Ant contribution to total bioturbation was $79 \%$ in the low-pH spruce forests, $24 \%$ in the pine forests, $5 \%$ in the grasslands and between 1 and $3 \%$ in the other vegetation types. The special study in the spruce forest at Uppsala with 11 Formica nests $\mathrm{ha}^{-1}$ indicated that the ant bioturbation was $0.7 \mathrm{Mg} \mathrm{dw} \mathrm{ha}{ }^{-1} \mathrm{y}^{-1}$. The same forest (humus layer $\mathrm{pH} 4.3$ ) had 200 epigeic earthworms $\mathrm{m}^{-2}$ corresponding to a bioturbation of $3 \mathrm{Mg} \mathrm{dw} \mathrm{ha}{ }^{-1} \mathrm{y}^{-1}$. Despite large ant nests and low soil $\mathrm{pH}$, the ant contribution was thus only $19 \%$ of total bioturbation.

\section{Discussion}

Earthworm and ant bioturbation varied strongly both between vegetation types and between replicate sites. This variation was largely expected as bioturbation is the outcome of many environmental factors that interact locally in their effect on earthworm and ant community composition, abundance and activity. The most striking overall pattern found was that sites and vegetation types lacking burrowing earthworms had low annual bioturbation and those with high abundance of these earthworms had high annual bioturbation. Most coniferous (pine and spruce) forests studied had few burrowing earthworms, and thus, bioturbation was low. One of the spruce forest plots at Forsmark was an exception with a combination of high $\mathrm{pH}$ in the topsoil $(>7)$ and fine soil texture, and the abundance/biomass of burrowing earthworms was atypically high. This was not only in comparison with the other coniferous plots investigated in the present study but also compared to Fennoscandian coniferous forests in general, where soils are often too acidic for burrowing earthworms (Satchell 1967; Edwards and Bohlen 1996; Brumme and Khanna 2009), and earthworms are often only represented by the small epigeic species D. octaedra (Räty and Huhta 2003). These results indicate that soil $\mathrm{pH}$ and texture can be of equal importance as vegetation type (Ando and others 2008) and litter quality (Marichal and others 2011; Rajapaksha and others 2013) in determining earthworm bioturbation, exerting an indirect effect on bioturbation via modulating species composition and abundance of earthworm community.

We hypothesized that earthworms would dominate annual bioturbation in vegetation types with a soil $\mathrm{pH}$ above 5, whereas ants would be more important bioturbators in acid soils. Our original hypothesis was partly based on the fact that red 
wood ants (Formica rufa group) can build enormous above-ground nests that can reach up to $2 \mathrm{~m}$ in height and $4 \mathrm{~m}$ in diameter (Gösswald 1989; Jurgensen and others 2008), and there can be abundances up to 18 nests ha ${ }^{-1}$ (Risch and others 2005), although 3 nests ha ${ }^{-1}$ is more common in Sweden (Kempe and Nilsson 2011). In addition, most earthworm species in temperate systems prefer a $\mathrm{pH}$ range of 5.0-7.0 and are very scare below $\mathrm{pH}$ 4.5 (Curry 2004). However, our results did not confirm our hypothesis because ant bioturbation was only found to be higher than earthworm bioturbation where very low $\mathrm{pH}$ restricted the presence of earthworms. When the $\mathrm{pH}$ of the humus layer was 4.3-4.5 or higher, epigeic earthworms were relatively abundant and their bioturbation exceeded that of the ants, even at high density of above-ground ant nests. Endogeic and anecic earthworms, which contributed most to earthworm bioturbation, were seldom found at $\mathrm{pH}$ 4.3-4.5 in the humus layers at Uppsala, but when they occurred in these acidic layers, the subsoil had always a $\mathrm{pH}$ close to 5 or higher.

Total bioturbation at vegetation types where anecic and endogeic earthworms were present ranged between 15 and $34 \mathrm{Mg} \mathrm{dw} \mathrm{ha-1} \mathrm{y}^{-1}$ with a mean of $25 \mathrm{Mg} \mathrm{dw} \mathrm{ha} \mathrm{h}^{-1} \mathrm{y}^{-1}$. These values correspond to soil turnover time of about 130-60 years, respectively, with a mean of 80 years assuming a topsoil of $20 \mathrm{~cm}$ depth consisting of $2000 \mathrm{Mg}$ fine $(<2 \mathrm{~mm})$ soil ha $^{-1}$ (Persson and others 2000). As expected, these values are relatively high, that is, turnover times are longer than those from similar vegetation types in more temperate parts of Europe, where a warmer climate allows for earthworms to be active during longer periods. Unfortunately, studies reporting bioturbation values from Scandinavian ecosystems are not available. In arable fields and grassland in Southern England, Evans (1948) calculated turnover time of 11-80 years and Graff and Makeschin (1979) estimated a turnover time of 4 years for meadow topsoil $(10 \mathrm{~cm})$ in Germany. In a study of a beechwood on limestone in Germany, Scheu (1987) reported that all endogeic earthworm species together produced around $60 \mathrm{Mg}$ dw faeces ha $\mathrm{h}^{-1} \mathrm{y}^{-1}$. When including the anecic $L$. terrestris, bioturbation of all burrowing earthworms in this German beechwood was calculated as $100 \mathrm{Mg}$ dw faeces $\mathrm{ha}^{-1} \mathrm{y}^{-1}$. Scheu (1987) calculated a turnover time of 18 years for the $20-\mathrm{cm}$ deep topsoil.

The varying results on bioturbation reported by different studies might depend on differences in earthworm abundance, soil temperature and soil water content, which in combination with tem- perature has a significant impact on earthworm feeding rates (Scheu 1987). During periods of higher temperature and low soil moisture, earthworms commonly move from the topsoil layers into deeper soil and become inactive (Edwards and Bohlen 1996), whereas severe drought can even reduce earthworm abundance (Eggleton and others 2009). Laboratory experiments at different water potentials have shown that the juvenile growth of A. caliginosa successively decreased when the water potential decreased from -2 to $-20 \mathrm{kPa}$ (Holmstrup 2001) and from 5 to $-54 \mathrm{kPa}$ (Eriksen-Hamel and Whalen 2006). In the present study, no measurements of gravimetric moisture content or water potential were taken. However, we know that during the summer months June and July in 2006, when our main study was made, precipitation was $75 \%$ lower than the long-term average at both Forsmark and Oskarshamn (SMHI 2013). This most likely resulted in sub-optimal moisture conditions for earthworms and an overestimation of earthworm bioturbation for these months.

Averaged over all vegetation types and sites, ant bioturbation in the present study was estimated as $450 \mathrm{~kg} \mathrm{dw} \mathrm{ha}{ }^{-1} \mathrm{y}^{-1}$ with Myrmica spp. and L. niger contributing the most. Our mean results on ant bioturbation were one order of magnitude lower than described in the literature, but in a single grassland plot we estimated ant bioturbation to be $2.4 \mathrm{Mg}$ soil ha ${ }^{-1} \mathrm{y}^{-1}$. Wilkinson and others (2009) summarized that most studies on ant bioturbation report 1-5 Mg soil ha $\mathrm{ha}^{-1}$. Other authors also mention bioturbation values in that range. A yearly bioturbation of $1-2 \mathrm{Mg}$ soil ha ${ }^{-1} \mathrm{y}^{-1}$ by L. flavus was observed by Seifert (1996), and Eldridge and Pickard (1994) estimated Aphaenogaster ants to move $2.2-4.7 \mathrm{Mg} \mathrm{ha}^{-1} \mathrm{y}^{-1}$ in a semi-arid area in Australia. The discrepancy to literature values maybe due to the low occurrence of large nests in the investigated vegetation types. Nevertheless, we consider the present results representative for ant bioturbation per se and for the relative importance of earthworm and ant bioturbation in the different vegetation types.

The equations developed in our study can be used to calculate earthworm bioturbation at any location provided that earthworm community data (species composition, biomass) and monthly soil temperatures are available. However, as the underlying experiments have been conducted with common European earthworm species and soil from local environments, we recommend to restrict the application of the formulas to communities with a comparable species composition as in the present study. However, many of these species are 
quite widespread not only in Europe (Rutgers and others 2016) but also in North America (Eisenhauer and others 2007) and Australia (Chan and others 2004).

Bioturbation by earthworms is partly a function of their egestion rates which is not only dependent on the food choice but is also affected by the digestive enzymes of the microbial community in the earthworm gut. The latter also consists of free bacteria in the ingested food source (Lavelle and others 2007) which are very likely to follow biogeographical patterns as have been shown for other microorganisms (Frey 2015), and mutualistic digestion systems between earthworms and microorganisms may strongly differ between climate regions. A drawback with the equations is that they do not include moisture effects on earthworm activity and assume optimum soil moisture levels during the whole year. For earthworm bioturbation estimated in the present study (for the year 2006), an overestimation for the dry months June and July can be assumed.

Studies that report quantitative data on bioturbation by ants and earthworms in the same ecosystems are few and are restricted to comparing above-ground mounding rates (Wilkinson and others 2009) which are higher for ants than for earthworms (Humphreys 1981; Mitchell 1988). In a comparison of funnel ants (Aphaenogaster longiceps) and earthworms in the temperate to sub-humid climate of the Sydney region, Australia, Humphreys (1981) reported a mounding rate of 8.41 $\mathrm{Mg} \mathrm{ha}^{-1} \mathrm{y}^{-1}$ for the ants in loamy sand, which was significantly higher than yearly aboveground earthworm casting ( $\left.1.33 \mathrm{Mg} \mathrm{ha}^{-1} \mathrm{y}^{-1}\right)$. In a study by Mitchell (1988) in a natural forest in the same area, the mounding rate for $A$. longiceps was much lower $\left(0.28 \mathrm{Mg} \mathrm{ha}^{-1} \mathrm{y}^{-1}\right)$ though still higher than for earthworms $\left(0.063 \mathrm{Mg} \mathrm{ha}^{-1} \mathrm{y}^{-1}\right)$. However, mounding rates are not reliable estimator of the relative impact of earthworms and ants in the same ecosystem, because species in both groups differ strongly in their contribution to mounding and subsurface mixing (Blanchard and others 1999; Richards 2009). In addition, particularly for earthworms-but probably also true for ants (see Richards 2009) - the largest part of bioturbation happens below-ground (Bouché 1981). Therefore, the present study focused on the total bioturbation of both groups.

The present study gives a first idea of the quantitative contribution of two important ecosystem engineers to ecosystem services. However, it is difficult to be more specific with regard to actual effect sizes and to extrapolate the consequences of changes in community composition and abundance for ecosystem services. In a forest management context, for example, clear felling and the associated soil disturbance by heavy machinery, ecosystem engineer communities may be severely affected with follow-up effects on water and gas exchange. These effects, for example, on soil drainage, may differ depending on the abundance and community composition of earthworms or ants.

\section{Conclusions}

Investigations of five vegetation types (mesic pine forest, mesic spruce forest, mesic broadleaf forest, moist alder carr and grazed/ungrazed grassland) in south-eastern Sweden showed that earthworms turned over far more soil than ants in most ecosystems. Ant bioturbation was higher than earthworm bioturbation only in some coniferous soils with topsoil $\mathrm{pH}$ lower than 4.3. In most other ecosystems where burrowing (endogeic and anecic) earthworms were present, mean soil bioturbation was $25 \mathrm{Mg} \mathrm{dw} \mathrm{ha}{ }^{-1} \mathrm{y}^{-1}$ of which the ants only contributed $2 \%$.

Thus, earthworms appear to be the dominant cause of bioturbation in most types of terrestrial ecosystems in the cold-temperate areas of Europe. When information on local earthworm communities and monthly soil temperatures is available, bioturbation in the respective habitats can be quantified using the presented 'earthworm bioturbation formula'.

In light of the strong environmental impacts of land use and climate change, it has become clear that we need a better understanding of the quantitative impact of functionally important soil organism, particularly those with ecosystem engineer status. Our approach is a first step towards linking empirical community data on ecosystem engineers with their function in a specific environment and their impact on ecosystem services. This link is needed to evaluate the functional consequences of community changes induced by anthropogenic or environmental disturbances (Brussaard and other 2012).

\section{ACKNOWLEDGEMENTS}

This work was part of an extensive study financed by the Swedish Nuclear Fuel and Waste Management Co (SKB) to elucidate various factors that can affect long-term storage of nuclear waste, for example mechanisms for the redistribution of radionuclides within the soil profile. In addition, we are grateful to U. Lohm for his work with 
earthworm growth and to A.F.S. Taylor for help with the studies on egestion rates.

\section{OPEN ACCESS}

This article is distributed under the terms of the Creative Commons Attribution 4.0 International License (http://creativecommons.org/licenses/by/4 $.0 /$ ), which permits unrestricted use, distribution, and reproduction in any medium, provided you give appropriate credit to the original author(s) and the source, provide a link to the Creative Commons license, and indicate if changes were made.

\section{REFERENCES}

Adhikari K, Hartemink AE. 2016. Linking soils to ecosystem services-a global review. Geoderma 262:101-11.

Andersen C. 1997. Regnorme. Nat Org Mus 36:1-35.

Ando M, Kita T, Kawahara T, Sugawara I. 2008. Comparison of earthworm communities between conifer plantations and broad-leaved secondary forests. J Agric Sci 53:144-51.

Axelsson B, Lohm U, Persson T. 1984. Enchytraeids, earthworms and soil arthropods in a northern deciduous woodland-a quantitative study. Holarct Ecol 7:91-103.

Barrios E. 2007. Soil biota, ecosystem services and land productivity. Ecol Econ 64:269-85.

Blanchart E, Albrecht A, Alegre J, Duboisset A, Gilot C, Pashanasi B, Lavelle P, Brussaard L. 1999. Effects of earthworms on soil structure and physical properties. In: Lavelle P, Brussaard L, Hendrix P, Eds. Earthworm management in tropical agroecosystems. Wallingford: CABI Publishing. p 149-72.

Blouin M, Hodson ME, Delgado EA, Baker G, Brussaard L, Butt KR, Dai J, Dendooven L, Peres G, Tondoh JE, Cluzeau D. 2013. A review of earthworm impact on soil function and ecosystem services. Eur J Soil Sci 64:161-82.

Bouché MB. 1977. Strategies lombriciennes. Ecol Bull 25:12232.

Bouché MB. 1981. Contribution des lombriciens aux migrations d'éléments dans les sols tempérés. Colloques Internationaux du Centre National de la Recherche Scientifique 303:145-53.

Brumme R, Khanna PK. 2009. Stand, soil and nutrient factors determining the functioning and management of beech forest ecosystems: a synopsis. Functioning and management of European beech ecosystems. Ecol Stud 208:459-90.

Brussaard L, Duur KA, Briones MJ, Decaëns T, De Deyn GB, Fayle TM, James SW, Nobre T. 2012. Biogeography and phylogenetic community structure of soil invertebrate ecosystem engineers: global to local patterns, implications for ecosystem functioning and services and global environmental change impact. In: Wall DH, Bardgett RD, Behan-Pelletier V, Herrick JE, Jones TH, Ritz K, Six J, Strong DR, van der Putten WH, Eds. Soil ecology and ecosystem services. Oxford: Oxford University Press. p 201-32.

Byzova JB. 1965. Comparative rate of respiration in some earthworms (Lumbricidae, Oligochaeta). Revue d'Ecologie et de Biologie du Sol 2:207-16.

Chan KY, Baker GH, Conyers MK, Scott B, Munro K. 2004. Complementary ability of three European earthworms (Lumbricidae) to bury lime and increase pasture production in acidic soils of south-eastern Australia. Appl Soil Ecol 26:25771.

Curry JP. 2004. Factors affecting the abundance of earthworms in soils. In: Edwards CA, Ed. Earthworm ecology. 2nd edn. Boca Raton: CRC Press. p 91-113.

Dostál P, Breznová M, Kozlicková V, Herben T, Kovár P. 2005. Ant-induced soil modification and its effect on plant belowground biomass. Pedobiologia 49:127-37.

Douwes P, Abenius J, Cederberg B, Wahlstedt U, Hall K, Starkenberg M, Reisborg C, Östmann T. 2012. Nationalnyckeln till Sveriges flora och fauna (National key to Sweden's flora and fauna). Stecklar: Myror-getingar. Hymenoptera: Formicidae-Vespidae. Uppsala (Sweden): ArtDatabanken (Swedish Species Information Center), SLU. p 382.

Edwards CA, Bohlen PJ. 1996. Biology and ecology of earthworms. London: Chapman and Hall. p 426.

Eggleton P, Inward K, Smit J, Jones DT, Sherlock E. 2009. A six year study of earthworm (Lumbricidae) populations in pasture woodland in southern England shows their responses to soil temperature and soil moisture. Soil Biol Biochem 41:1857-65.

Eisenhauer N, Partsch S, Parkinson D, Scheu S. 2007. Invasion of a deciduous forest by earthworms: changes in soil chemistry, microflora, microarthropods and vegetation. Soil Biol Biochem 39:1099-110.

Eldridge DJ, Pickard J. 1994. Effects of ants on sandy soils in semi-arid Eastern Australia: II. Relocation of nest entrances and consequences for bioturbation. Aust J Soil Res 32:323-33.

Eriksen-Hamel NS, Whalen JK. 2006. Growth rates of Aporrectodea caliginosa (Oligochaetae: Lumbricidae) as influenced by soil temperature and moisture in disturbed and undisturbed soil columns. Pedobiologia 50:207-15.

Evans AC. 1948. Studies on the relationships between earthworms and soil fertility, II: some effects of earthworms on soil structure. Ann Appl Biol 34:307-30.

Folgarait PJ. 1998. Ant biodiversity and its relationship to ecosystem functioning: a review. Biodivers Conserv 7:122144.

Frey SD. 2015. The spatial distribution of soil biota. In: Paul EA, Ed. Soil microbiology, ecology and biochemistry. Amsterdam: Elsevier. p 223-44.

Frouz J, Jilková V. 2008. The effect of ants on soil properties and processes (Hymenoptera: Formicidae). Myrmecol News 11:191-9.

Gösswald K. 1989. Die Waldameise. Band 1. Biologische Grundlagen, Ökologie und Verhalten. Wiesbaden: AULA.

Graff O, Makeschin F. 1979. Der Einfluß der Fauna auf die Stoffverlagerung sowie die Homogenisierung und die Durchlässigkeit von Böden. Zeitschrift für Pflanzenernährung und Bodenkunde 142:476-91.

Hale CM. 2007. Earthworms of the Great Lakes. Duluth (Minn.): Kollath and Stensaas Publishing. p 47.

Hedde M, Lavelle P, Joffre R, Jiménez JJ, Decaëns T. 2005. Specific functional signature in soil macro-invertebrate biostructures. Funct Ecol 19:785-93.

Holmstrup M. 2001. Sensitivity of life history parameters in the earthworm Aporrectodea caliginosa to small changes in soil water potential. Soil Biol Biochem 33:1217-23.

Humphreys GS. 1981. The rate of ant mounding and earthworm casting near Sydney, New-South-Wales. Search 12:129-31.

Hölldobler B, Wilson EO. 1990. The ants. Berlin: Springer. p 732. 
Jakubczyk H, Czerwínski Z, Petal J. 1972. Ants as agents of the soil habitat changes. Ekologia Polska 16:153-61.

Jones CG, Gutiérrez JL. 2007. On the purpose, meaning, and usage of the physical ecosystem engineer concept. In: Cuddington K, Byers JE, Wilson WG, Hastings A, Eds. Ecosystem engineers: plants to protists. Amsterdam: Academic Press. p 324.

Jurgensen MF, Finér L, Domisch T, Kilpeläinen J, Punttila $\mathrm{P}$, Ohashi M, Niemelä P, Sundström L, Neuvonen S, Risch AC. 2008. Organic mound-building ants: their impact on soil properties in temperate and boreal forests. J Appl Entomol $132: 266-75$.

Kempe G, Nilsson T. 2011. Uppföljning av miljötillståndet i skog baserat på Riksskogstaxeringen. Framtagen av länsstyrelsen i Norrbottens län i samband med SLU och skogsstyrelsen. Länsstyrelsen Västernorrland avdelningen för miljö och natur (2011:22)

Laakso J, Setälä H. 1998. Composition and trophic structure of detrital food web in ant (Formica aquilonia) nest mounds and in the surrounding soil. Oikos 81:266-78.

Lavelle P, Bignell D, Lepage M, Wolters V, Roger P, Ineson P, Dhillion OW. 1997. Soil function in a changing world: the role of invertebrate ecosystem engineers. Eur J Soil Biol 33:15993.

Lavelle P, Decaëns T, Aubert M, Barot S, Blouin M, Bureau F, Margerie P, Mora P, Rossi J-P. 2006. Soil invertebrates and ecosystem services. Eur J Soil Biol 42:3-15.

Lavelle P, Barot S, Blouin M, Decaëns T, Jimenez JJ, Jouquet P. 2007. Earthworms as key actors in self-organised soil systems. In: Cuddington $\mathrm{K}$, Byers JE, Wilson WG, Hastings A, Eds. Ecosystem engineers-plants to protists. Amsterdam: Elsevier. p 77-106.

Le Bayon R-C, Bullinger-Weber G, Schomburg A, Turberg P, Schlaepfer R, Guenat C. 2017. Earthworms as ecosystem engineers: a review. In: Horton CG, Ed. Types, roles and research. New York: Nova Science Publishers. p 129-77.

Lobry de Bruyn LA, Conacher AJ. 1994. The bioturbation activity of ants in agricultural and naturally vegetated habitats in semi-arid environments. Aust J Soil Res 32:555-70.

Lofs-Holmin A. 1983. Reproduction and growth of common arable land and pasture species of earthworms (Lumbricidae) in laboratory cultures. Swed J Agric Res 13:31-7.

Lundin L, Lode E, Stendahl J, Melkerud P-A, Björkvald L, Thorstensson A. 2004. Soils and site types in the Forsmark area. SKB (Swedish Nuclear Fuel and Waste Management) Report, R-04-08, p 102.

Lundin L, Lode E, Stendahl J, Björkvald L, Hansson J. 2005. Oskarshamn site investigation. Soils and site types in the Oskarshamn area. SKB Report, R-05-15, p 96.

Marichal R, Mathieu J, Couteaux M-M, Mora P, Royc J, Lavelle P. 2011. Earthworm and microbe response to litter and soils of tropical forest plantations with contrasting C:N: P stoichiometric ratios. Soil Biol Biochem 43:1528-35.

Meysman FJR, Middelburg JJ, Heip CHR. 2006. Bioturbation: a fresh look at Darwin's last idea. TREE 21:688-95.

Mitchell P. 1988. The influences of vegetation, animals and micro-organisms on soil processes. In: Viles HA, Ed. Biogeomorphology. Oxford: Basil Blackwell LTD. p 43-83.

Persson T, Lohm U. 1977. Energetical significance of the annelids and arthropods in a Swedish grassland soil. Ecol Bull 23:211.
Persson T, Van Oene H, Harrison AF, Karlsson PS, Bauer GA, Cerny J, Coûteaux M-M, Dambrine E, Högberg P, Kjøller A, Matteucci G, Rudebeck A, Schulze E-D, Paces T. 2000. Experimental sites in the Niphys/Canif project. Ecol Stud 142:14-46.

Persson T, Lenoir L, Vegerfors B. 2017. Long-term effects of stump harvesting and site preparation on pools and fluxes of soil carbon and nitrogen in central Sweden. Scand J For Res 32:222-9.

Rajapaksha NSS, Butt KR, Vanguelova EI, Moffat AJ. 2013. Earthworm selection of short rotation forestry leaf litter assessed through preference testing and direct observation. Soil Biol Biochem 67:12-19.

Räty M, Huhta V. 2003. Earthworms and pH affect communities of nematodes and enchytraeids in forest soil. Biol Fertil Soils 38:52-8.

Richards PJ. 2009. Aphaenogaster ants as bioturbators: impacts on soil and slope processes. Earth Sci Rev 96:92-106.

Risch AC, Jurgensen MF, Schütz M, Page-Dumroese DS. 2005. The contribution of red wood ants to soil $\mathrm{C}$ and $\mathrm{N}$ pools and $\mathrm{CO}_{2}$ emissions in subalpine forests. Ecology 86:419-30.

Rutgers M, Orgiazzi A, Gardi C, Römbke J, Jänsch S, Keith AM, Neilson R, Boag B, Schmidt O, Murchie AK, Blackshaw RP, Pérès $G$, Cluzeau D, Guernion $M$, Briones MJI, Rodeiro $J$, Piñeiro R, Díaz Cosín DJ, Sousa JP, Suhadolc M, Kos I, Krogh P-H, Faber JH, Mulder C, Bogte JJ, van Wijnen HJ, Schouten AJ, de Zwart D. 2016. Mapping earthworm communities in Europe. Appl Soil Ecol 97:98-111.

Satchell JE. 1967. Lumbricidae. In: Burges A, Raw F, Eds. Soil biology. New York: Academic Press. p 259-322.

Scheu S. 1987. The role of substrate feeding earthworms (Lumbricidae) for bioturbation in a beechwood soil. Oecologia 72:192-6.

Scheu S. 2003. The role of substrate feeding earthworms: patterns and perspectives. Pedobiologia 47:846-56.

Seifert B. 1996. Ameisen beobachten, bestimmen (In German). Augsburg: Naturbuch Verlag. p 351.

Sims RW, Gerard BM. 1985. Earthworms: keys and notes for the identification and study of the species. Synop Br Fauna (New Series) 31:173.

SMHI (Swedish Meteorological and Hydrological Institute) 2013. http://www.smhi.se/klimatdata/meteorologi/dataserier-2.110 2.

Staaf H, Persson T, Bertills U. 1996. Skogskalkning. Resultat och slutsatser från Naturvårdsverkets försöksverksamhet. Naturvårdsverket Rapport 4559. p 290 (In Swedish).

Taylor AR, Taylor AFS. 2014. Assessing daily egestion rates in earthworms: using fungal spores as a natural soil marker to estimate gut transit time. Biol Fertil Soils 50:179-83.

Turbé A, De Toni A, Benito P, Lavelle P, Lavelle P, Ruiz N, Van der Putten WH, Labouze E, Mudgal S. 2010. Soil biodiversity: functions, threats and tools for policy makers. Bio Intelligence Service, IRD, and NIOO, Report for European Commission (DG Environment).

Wall DH, Bardgett RD, Behan-Pelletier V, Herrick JE, Jones TH, Ritz K, Six J, Strong DR, van der Putten WH, Eds. 2012. Soil ecology and ecosystem services. Oxford: Oxford University Press. p 414

Wilkinson MT, Richards PJ, Humphreys GS. 2009. Breaking ground: Pedological, geological and ecological implications of soil bioturbation. Earth Sci Rev 97:257-72. 